\title{
What Motivates Consumers to Purchase Organic Food in Malaysia?
}

\author{
Song Bee Lian ${ }^{1}$ \\ ${ }^{1}$ Faculty of Business, Accounting and Management, SEGi University, Selangor, Malaysia \\ Correspondence: Song Bee Lian, Faculty of Business, Accounting and Management, SEGi University, No.9, \\ Jalan Teknologi, Taman Sains Selangor, Kota Damansara, PJU5, 47810 Petaling Jaya, Selangor, Malaysia. Tel: \\ 603-61451777. E-mail: blsong@segi.edu.my
}

Received: June 18, 2017

doi:10.5539/ass.v13n9p100
Accepted: July 5, $2017 \quad$ Online Published: August 25, 2017

URL: https://doi.org/10.5539/ass.v13n9p100

\begin{abstract}
The aim of this study is to investigate the consumer motivational factors that influence their attitude to purchase of organic food in Malaysia. Consumer motivational factors involved past experience, health consciousness and personal values were examined in this study. Data from 421 organic food consumers were obtained through a survey conducted in Kuala Lumpur and Petaling Jaya or better known as Klang Valley, Malaysia. The structural equation modelling was used for data analysis and four hypotheses were tested. The findings showed that all four hypotheses were accepted. Health consciousness had the greatest positive influence on consumer attitude of organic food, followed by past experience and personal values. Purchase of organic food products was significantly affected by consumer attitude of the products. The contribution of this paper is twofold. First and from a theoretical perspective, it offers both development and validation of Theory of Planned Behaviour and Hierarchy of Effect model. Second and from a pragmatic perspective, the findings proposed useful information to organic food providers in developing and implementation of effective strategies to enhance consumption of organic food.
\end{abstract}

Keywords: organic food, consumer attitude, health consciousness, personal value

\section{Introduction}

Organic food is the fastest growing market in the food industry in many countries (Dettman \& Dimitri, 2010). The global sales for organic food and beverage have reached US\$89.8 billion in 2015 (Stratistics Market Research Consulting, 2016). Economic growth, urbanisation, globalisation and trade liberalisation has significantly impact consumers' food choices and preferences. The increasing consumers' demand towards organic food products are mainly due to food safety concern (Hsu, Chang \& Lin, 2016; Wee, Ariff, Zakuan \& Tajuddin, 2014), health benefits (Mohamad, Rusdi \& Hashim, 2014) and environmental concern (Sia, Ooi, Chong, Lim \& Low, 2013).

According to Schiffman (2008), consumer behaviour is influenced by internal and external factors. Internal influences are processes that occur primarily within an individual consumer decision making and is influenced by psychological factors such motivation, perception, learning, personality, and attitude (Schiffman and Kanuk, 2007). Hence, the important internal stimuli factors that influencing consumer attitude to purchase organic food products are health consciousness (Tregear, Dent \& McGregor, 1994), personal values (Zanoli, 2004) and past experience (Bo, 2009). Past literature have debated on what are the factors motives the consumers to purchase organic food products. Several researchers have also questioned on the contribution of organic food towards health benefits (Dangour, Lock, Hayter, Aikenhead, Allen \& Uauy, 2010; Magnusson, Arvola, Hursti, Aberg \& Sjoden, 2003). Furthermore, consumers have different perspectives on personal values when purchasing organic food (Sashi, Kottala \& Singh, 2015). Consumers' personal values include health benefits (Mohamad, et al., 2014), environmental concern (Sia et al., 2013), high quality (Basha, Mason and Shamsudin, 2015) and better taste (Denver and Jensen, 2014) of organic food products significantly affect customer attitude to purchase.

This exploratory study is aimed to investigate how motivational factors influence consumer attitude to purchase of organic food in Klang Valley, Malaysia. Hence, the primary objectives of this study are; 1) to investigate the effect of past experience, health consciousness and personal values on consumer attitude of organic food and 2) to analyse the influence of consumer attitude towards purchase of organic food.

This study has integrated the Theory of Planned Behaviour (TPB) and Hierarchy of Effects Model (HEM) in the 
development of conceptual framework. Past research on organic food have generated extensive insights into motives for purchasing organic food products. However, little attempt of past research studies that have adopted an established theory or theoretical approach to explain a purchase behavior of organic food (Lee \& Goudeau, 2014). For example, the TPB model has been criticized due to the lack of a past experience component in relating to consumer purchasing behaviour (Bo, 2009). Hence, this study is expected to fill up the research gap and contribute to the development and validation of TPB and HEM in the context of consumer purchasing behaviour of organic food industry. The findings of this research will provide better understanding on the internal stimuli factors that influencing consumer attitude to purchase organic food. Furthermore, the organic food retailers or manufacturers could leverage on this findings for better planning, formulation and implementation of marketing strategies to the targeted consumers.

\section{Literature Review and Hypotheses Development}

\subsection{Associated Theories}

The TPB has been widely applied in most of the studies to reflect the social cognition in psychology. TPB is an extension of the Theory of Reasoned Action (TRA), with enhancement by its addition of perceived behavioural control (Ajzen 1991). The TRA was first introduced by Fishbein and Ajzen in 1967 (Ajzen and Fishbein, 1980; Fishbein and Ajzen, 1975). TRA focused on explaining and exploring the 'knowledge-attitudes-behaviour', as well as the underlying determinants of intentions and behaviour (Fishbein and Ajzen, 1975).

The Hierarchy of Effects Model (HEM) was introduced by Lavidge and Steiner (1961) and later adapted by Barry and Howard (1990). This model indicates that consumers will go through different mental stages during making purchasing decisions and reaction to messages in sequence basis. The HEM process includes cognitive (learning, knowing), affective (thinking, feeling) and conative (intending, doing) components. The HEM model applied well in understanding consumer attitude and behaviour (Dubé, Cervellon and Han, 2003). A few previous literature have applied and tested HEM in their conceptual framework, such as Chen (2009), Khan (2012), Lee \& Goudeau (2014). Khan (2012) found that all seven independent variables under cognitive stage represented by attitude, subjective norms, perceive price, health consciousness, availability, knowledge and demographic characteristics were significant to purchase intention (affective stage) and actual purchase (conative stage). In a study conducted by Lee \& Goudeau (2014), beliefs and utilitarian attitudes are conceptualized as cognition; hedonic attitudes, as affect; and attitudinal loyalty and behavioral loyalty, as behavior. Lee \& Goudeau (2014) found that health benefits positively influenced utilitarian attitudes, and also utilitarian attitudes had a significant relationship with hedonic attitudes, which in turn led to attitudinal loyalty.

\subsection{Past Experience}

According to the Social Cognitive Theory (Bandura, 2001), individual process of learning is influenced by external and internal social reinforcement. Reciprocal determinism elaborated the dynamic and reciprocal interaction of an individual which comprises a set of learned experience and personal characteristics which interact with external social context to enable a certain behavior, such as attitude or purchasing behavior. A few researchers (e.g., Bo, 2009; Verbeke \& Vackier, 2005) have found that past experience is an important factor influencing consumer attitude to purchase products or services. In a study at South Korea, Bo (2009) reported that past experience have a positively significant influenced on consumers' purchase intention of organic food. In fact, past experience was the most important factor being compared to other variables, such as trust, price, and perceived behavioural control, used in the study (Bo, 2009). Verbeke \& Vackier (2005) examined individual determinants in purchasing fish by using TPB model and concluded that habit emerged as the strongest determinant of purchasing behavior.

In contrast, Rahman, Aafzal, Mahmood \& Habib (2015) conducted an empirical investigation on Pakistani organic food consumers, and asserted that past experience has no significant impact on purchase intention of organic food. Past experience was not an important element in motives to purchase organic food due to the cultural setting in a less developed country like Pakistan (Rahman et al., 2015). Hence, to explore the relationship between the past experience and consumer attitude of organic food, the following hypothesis is developed:

\section{$H_{1}$ : Past experience has significant effect on consumer attitude of organic food.}

\subsection{Health Consciousness}

Health consciousness refers to the desired state of well-being and emphasize to maintain a healthy life. Previous studies have identified that health consciousness is the most commonly stated motives for purchasing organic food (e.g., Basha et al., 2015; Sia et al., 2013; Chen, 2009; Roitner-Schobesberger, Darnhofer, Somsook \& Vogl, 
2008; Padel \& Foster, 2005). Generally, consumers believed that organically grown foods are safer, higher nutritional value and provide greater health benefits than conventional alternatives and this has leads to positive attitudes toward organic food products (Sia et al., 2013). In a study conducted in U.S, Lee and Goudeau (2014) found that health convictions were decidedly connected with consumers' attitude to purchase organic food. According to Chen (2009), healthy lifestyle as an important mediating effects on the positive relationships between health consciousness and consumer attitude towards organic food. Magnusson et al. (2003) found that health consciousness positively influenced the Swedish consumers' attitude to purchase organic food. Consumers prioritised on organic food for own or family health as the strongest motivations to purchase organic food (Makatouni, 2002; Magnusson, Arvola, KoivistoHursti, Aberg \& Sjode'n, 2001). Consumers have positive attitude towards organic food because they believed by consuming organic food, which are free from pesticide residues, would improve their health (Lockie, Lyons, Lawrence \& Mummery, 2002).

In contrast, Tarkiainen \& Sundqvist (2015) and Michaelidou \& Hassan (2008) found that the relationship between health consciousness and consumer attitude to purchase organic food was not significant. Food safety concern and ethical self-identity was identified more important than health consciousness as motives to purchase organic food (Tarkiainen \& Sundqvist, 2005; Brunso \& Scholderer, 2001). Hence, the following hypothesis is developed to explore the relationship between health consciousness and consumer attitude:

\section{$\mathrm{H}_{2}$ : Health consciousness has significant effect on consumer attitude of organic food.}

\subsection{Personal Values}

According to Schwartz Value Inventory (Schwartz, 1992), values can be categorised into conservatism, self-enhancement, self-transcendence and openness to change. Self-enhancement focuses on consumers who prioritised on social status as their motives to purchase organic food. Conservatism refers to the belief to support stability of society and social relationships, such as support the growth of local organic food industry. Self-transcendence advocated universalism by focusing on contribution towards environmental friendly, ecology and protects animal welfare. Openness to change relates to the desire to change their lifestyle, practice healthier eating habit, or try new innovative organic food.

A few researchers (e.g., Sia, 2013; Basha et al., 2015; Sangkumchaliang \& Huang, 2012) have asserted that environmental concern was a major determinant of purchasing organic food. According to Basha et al. (2015), the increasing awareness on environmental degradation has changed consumer attitude to purchase more environmental-friendly and organic products. Pellegrini \& Farinello (2009) reported that majority of respondents in their study perceived by purchasing organic food would help save the environment. Honkanen, Verplanken \& Olsen (2006) concluded the more concerned consumer attitude towards environmental friendly, the more positive their attitude on purchasing organic food. Ethical concern on animal welfare was an important influencing factor in decision to purchase organic food (Harper \& Makatouni, 2002).

Lifestyle is also the most important factors for the motives to purchase organic food (Basha et al., 2015; Zanoli et al., 2004). Additionally, organic food products are seen represent status symbols or affluent lifestyle (Padel \& Foster, 2005; Govindasamy, DeCongelio, Italia, Baobour \& Anderson, 2001). Organic food has a social value (Costa, Zepeda \& Sirieix, 2011). Consumers who have been convinced of the values obtained from organic food consumption and have adopted organic lifestyle were able to accept the higher price (Voon, Kwang \& Agrawal, 2011). Organic food is seen as more of a 'luxury good,' where higher price tag gives the purchaser a feeling of high product quality and social esteem (Govindasamy et al., 2001).

$H_{3}$ : Personal values has significant effect on consumer attitude of organic food.

\subsection{Attitude}

An attitude is a psychological tendency that is expressed by evaluating a particular entity with some degree of favour or disfavour (Ajzen, 1985). In the conceptual framework for this study, we will combine the three classical dimensions of attitude formation known as Hierarchy of Effect Model (Barry \& Howard, 1990 ), e.g. a cognitive (motivations to purchase organic food), an affective (general attitudes towards organic food), and a conative dimension (purchase of organic food). Theory of Planned Behaviour indicated three major determinants: attitudes towards the behaviour, subjective norms and perceptions of behavioural control (Ajzen 1991; Ajzen 2005; Ajzen \& Albarracin 2007). Consumer attitude is proven to be one of the most important antecedents of understanding and explaining consumers' choice of food (Conner, Povey, Sparks, James \& Shepherd, 2003).

\subsection{Purchase}

According to the TPB (Ajzen \& Albarracin, 2007), actual purchase is the important final stage in the consumers' process of buying a product or service. Song, Safari \& Mansori (2016) found that consumer attitude is positively 
correlated to the actual purchase of organic food. Lim, Li \& Suryadi (2014) examined and found positive relationship between purchase intention and actual purchase of organic food. Wee et al. (2014) reported that actual purchase behaviour of organic food products was significantly affected by the purchase intention of the products. Past literature in the context of organic food study in Malaysia had little attempt in investigating this final stage of actual purchase (Wee et al., 2014). Furthermore, Pearson, Henryks \& Jones (2010) stated that exist a gap of knowledge in the aspect of consumers generally have positive attitude towards organic food, but relatively low level of actual purchases. Hence, the following hypothesis is formed to address the gap by investigating the relationship between consumer attitude and purchase.

$H_{4}$ : Consumer attitude is directly and positively correlated to the purchase of organic food.

\section{Conceptual Model}

Figure 1 shows the conceptual model for this study. The independent variables of past experience, health consciousness and personal values representing the motivational factors. Consumer attitude as mediator and purchase as dependent variable.

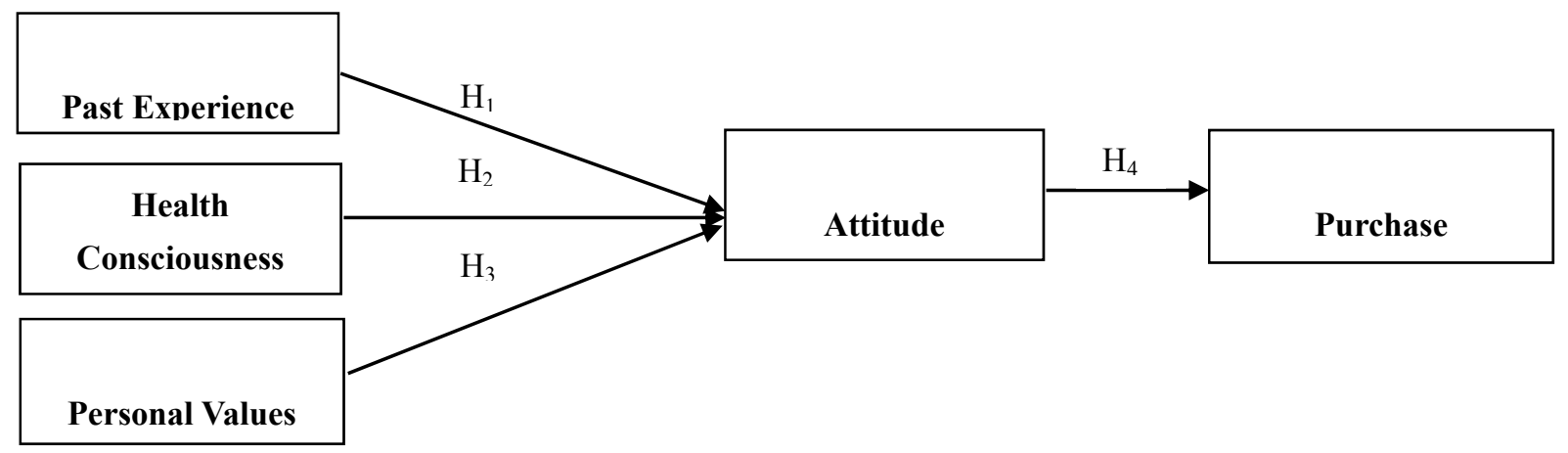

Figure 1. Conceptual Model

\section{Methodology}

\subsection{Sampling and Measurement}

The target population of this study is existing consumer of organic food residing in Klang Valley, Malaysia. Non-probability convenience sampling method was used to select the sample of 421 respondents who were consumers present at the selected supermarkets or specialty retail outlets selling organic food products (Aeon, Country Farm Organics and BMS Organic) in Klang Valley, Malaysia. A pilot study was conducted on 100 respondents to ensure respondent's comprehension of the questionnaires. The survey instrument was designed with 23 items assessed by a six-point Likert scale (1: strongly disagree and 6: strongly agree) and demographic variable with four items. The scale measured past experience, health consciousness, personal values, consumer attitude and purchase. The collected data was analysed using the Statistical Package for Social Sciences (SPSS) version 22 to perform descriptive analysis, validity and reliability analysis. Followed by, SPSS AMOS version 21 was used to perform the SEM analysis to test the hypotheses.

\subsection{Validity and Reliability Assessment}

According to Hair, Black, Babin, Anderson and Tatham (2010), the objectives of pilot study is to perform Exploratory Factor Analysis (EFA) to eliminate variables with factor loading less than 0.3. Pallant (2007) has suggested that Bartlett's Test of Sphericity value must be significant at $\mathrm{p}<0.05$ and the Kaiser-Meyer-Olkin (KMO) value must be 0.6 or above. In examining EFA using Maximum Likelihood extraction and Promax rotation, it has yielded five dimensions (KMO score of 0.888 , Bartlett's Test $\mathrm{p}=0.000, \mathrm{p}<0.05$ ). The factor loading for all the 23 proposed items is above 0.3. The Confirmatory Factor Analysis (CFA) for each item in the construct and Cronbach's Alpha results are presented in Table 1. The Cronbach's Alpha values of 0.7 and above are required to show a high level of internal consistency in the data (Pallant, 2007). The Cronbach's Alpha values were 0.959 (past experience), 0.868 (health consciousness), 0.918 (personal values), 0.906 (attitude) and 0.888 (purchase). Hence, the findings indicated that past experience, health consciousness, personal values, attitude and purchase of organic food were valid and reliable for further inferential analyses. 
Table 1. The CFA Results for the Measurement Model

\begin{tabular}{|c|c|c|c|c|}
\hline Construct & Item & Statement & $\begin{array}{c}\text { Factor } \\
\text { Loading }\end{array}$ & $\begin{array}{l}\text { Cronbach's } \\
\text { Alpha }\end{array}$ \\
\hline \multirow{6}{*}{$\begin{array}{l}\text { Past } \\
\text { Experience }\end{array}$} & $\mathrm{X} 1$ & I have a positive experience on organic food. & .852 & .959 \\
\hline & $\mathrm{X} 2$ & I usually purchase organic food more than conventional food. & .909 & \\
\hline & $\mathrm{X} 3$ & I am very satisfied with the consumption of organic food. & .915 & \\
\hline & $\mathrm{X} 4$ & I purchased and consumed various types of organic food. & .903 & \\
\hline & $\mathrm{X} 5$ & I purchased and consumed organic food due to its innovativeness. & .885 & \\
\hline & $\mathrm{X} 6$ & Organic food is always easily available for purchase. & .891 & \\
\hline \multirow{5}{*}{$\begin{array}{l}\text { Health } \\
\text { Consciousness }\end{array}$} & H1 & $\begin{array}{l}\text { Organic food is more nutritional than conventional food that improves my } \\
\text { health. }\end{array}$ & .688 & .868 \\
\hline & $\mathrm{H} 2$ & $\begin{array}{l}\text { Organic food is safe for consumption as it is free from pesticides, fertilizers and } \\
\text { genetic modifications. }\end{array}$ & .790 & \\
\hline & H3 & Organic food products are healthier than conventionally grown food. & .784 & \\
\hline & $\mathrm{H} 4$ & Organic food is better in quality that promotes my health. & .828 & \\
\hline & H5 & Organic food provided me a healthy lifestyle. & .697 & \\
\hline \multirow{4}{*}{$\begin{array}{l}\text { Personal } \\
\text { Values }\end{array}$} & $\mathrm{V} 1$ & $\begin{array}{l}\text { I purchase organic foods to contribute towards environmental friendly, ecology } \\
\text { and protects animal welfare. }\end{array}$ & .782 & .918 \\
\hline & $\mathrm{V} 2$ & Organic food contribute to higher status symbol. & .936 & \\
\hline & $\mathrm{V} 3$ & I purchased organic foods to support local organic food industry. & .922 & \\
\hline & V4 & Organic food is tastier than normal conventional food. & .812 & \\
\hline \multirow{4}{*}{ Attitude } & A1 & I trust the product labelled as organic. & .831 & .906 \\
\hline & $\mathrm{A} 2$ & In general, I hold a positive attitude on organic food. & .849 & \\
\hline & A3 & I am willing to purchase organic food because the benefits outweigh the costs. & .823 & \\
\hline & A4 & I have positive intention to purchase organic food. & .803 & \\
\hline \multirow{4}{*}{ Purchase } & $\mathrm{P} 1$ & I am a regular purchaser of organic food. & .835 & .888 \\
\hline & $\mathrm{P} 2$ & $\begin{array}{l}\text { My purchase proportion of organic food is relatively higher compared to } \\
\text { non-organic food. }\end{array}$ & .819 & \\
\hline & P3 & I purchased organic food for my own consumption. & .817 & \\
\hline & $\mathrm{P} 4$ & I purchased organic food as a gift for my friends. & .791 & \\
\hline
\end{tabular}

\section{Findings}

\subsection{Demographic Profile of the Respondents}

A total of 421 respondents were existing consumers of organic food. Majority respondents are female (60\%), followed by male (40\%). As for the respondents' monthly income, 4.5 percent earned less than RM1500, 13.3 percent of the respondents have an income between RM1500- RM3000. Furthermore, 41.1 percent of the respondents have an income between RM3000-R,M6000 and 32.3 percent of the respondents belong to the income group of RM6000-RM10000. Respondents with an income above RM 10000 comprises 8.8 percent. As for the respondents' age, 8.6 percent belong to the age group of 18-20, followed by 23.5 percent under the age group between $21-38$. Majority of 46 percent of the respondents under the age group of 39-49, and 21.9 percent belong to age group of 50 and above. In addition, majority of respondents come from high educated category which are bachelor degree $(49.4 \%)$, post-graduate $(16.4 \%)$, certificate or diploma $(25.4 \%)$, and high school and below (8.8\%).

\subsection{Model Compatibility Testing}

Table 2. Goodness of Fit

\begin{tabular}{cccc}
\hline Index & Level of Acceptance & Result & Model Evaluation \\
\hline Chi-square & P $>0.05$ & 599.601 & Good \\
Chisq $/$ df & Chi Square $/$ df $<3.0$ & 2.689 & Good \\
RMSEA & RMSEA $<0.08$ & 0.063 & Good \\
IFI & IFI $>0.9$ & 0.951 & Good \\
CFI & CFI $>0.9$ & 0.951 & Good \\
TLI & TLI $>0.9$ & 0.944 & Good \\
\hline
\end{tabular}


This study accounted a good fit of the research model to the data as shown in Table 2. The Chi-Square value is 599.601 and according to Barrett (2007), chi square probability value greater than 0.05 indicates acceptable model fit. The ratio of $x^{2} / \mathrm{df}$ was 2.689, lower than the value 3.0, as suggested by Byrne (2010). Incremental fit indices were greater than 0.9 , with IFI of 0.951 , CFI of 0.951 and TLI of 0.944 . As for the absolute index, RMSEA of 0.063 which was lower than the value 0.8, as suggested by Browne and Cudeck (1993).

The normality assessment was conducted to assess the distribution for every variable in the dataset before proceeding to modelling the structural model. By using SEM with Maximum Likelihood Estimator, the findings indicated that the data is normally distributed with value of skewness between -1.0 and 1.0, and kurtosis of between -3.0 and 3.0. Finally, the estimated path coefficients were derived and the research hypotheses were examined.

\subsection{Model Causality Testing}

The regression weights and probability value which indicates its significance is shown in Table 3 and final structural model is shown in Figure 2. The findings concluded that past experience had significant positive effect (0.212) on attitude and $\mathrm{H}_{1}$ is accepted. $\mathrm{H}_{2}$ is accepted and health consciousness has significant effect on attitude of organic food (0.136). The regression coefficient of the relationship between personal values and attitude is also significant (0.512) and $\mathrm{H}_{3}$ is accepted. Subsequently, attitude had direct positive effect (0.472) on purchase and shown significant $\mathrm{P}$ value. Therefore, $\mathrm{H}_{4}$ which proposed attitude has a positive influence on purchase of organic food is accepted.

Table 3. Regression Weights and the Probability Value which Indicates its Significance

\begin{tabular}{cccccccc}
\hline Paths & & & Estimate & S.E. & C.R. & P & Result \\
\hline Attitude & $<--$ & Past Experience & .212 & .039 & 5.440 & $* * *$ & Supported \\
Attitude & $<--$ & Personal Values & .136 & .061 & 2.224 & .026 & Supported \\
Attitude & $<--$ & Health Consciousness & .512 & .076 & 6.766 & $* * *$ & Supported \\
Purchase & $<--$ & Attitude & .472 & .040 & 11.734 & $* * *$ & Supported \\
\hline
\end{tabular}

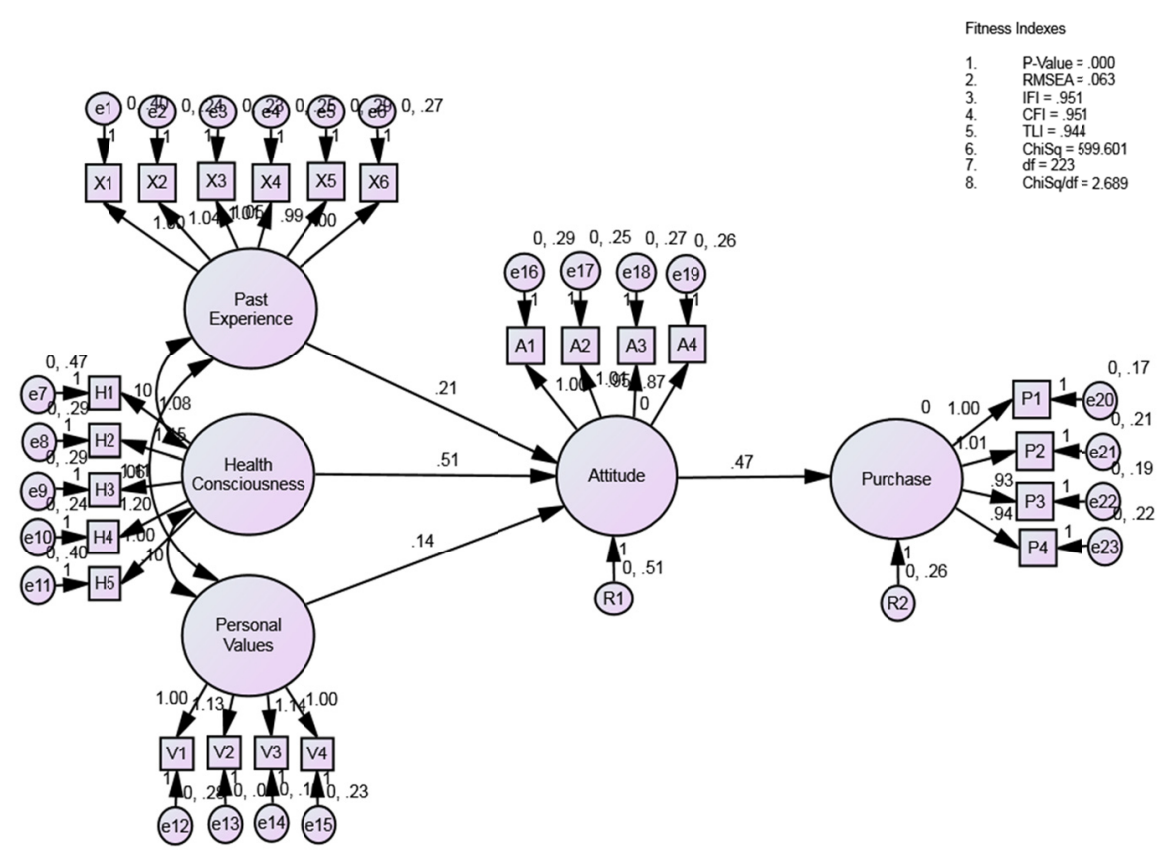

Figure 2. Structural Model

\section{Discussion}

Empirical results in this study indicate that consumers' strong concerns about health was the main motivation 
factor for their positive attitude towards purchasing of organic food. Hypothesis 2 is accepted and the findings are consistent with many previous studies (e.g. Sia et al., 2013; Lee \& Goudeau, 2014; Chen, 2009). This implies that consumers believed that organic food products are better in nutritional values, quality, safety and health benefits. Although hypothesis 1 and 3 are accepted, but its correlation coefficient value still considered as weak according to 'Guilford Rule of Thumb', with $\mathrm{r}$ value of below 0.4 (Guilford, 1956).

It is recommended that organic food manufacturers and retailers should prioritised on the nutritional value, long term health benefits, environmental concern and social status when producing or selling the products. Most of the products should carry the organic certification logos to build consumers' trust and encourage positive attitude to purchase organic food. The communication flow with the consumers should be maintained systematic and clear information on the benefits and characteristics of organic food. Marketers should convince the consumers that organic food product is safe for health and consists good values, because these motivational factors support the positive attitude a to purchase organic food.

The policymakers could leveraged on this study findings to further promote the organic certification logo and organic food knowledge to the public through a nation-wide awareness campaigns. Malaysian consumers preferred to purchase organic food products with proper organic certification as it is viewed as being more trustworthy. Policy concerning health awareness and placement to generate more consumption volume even if the price is a barrier.

The foremost theoretical contribution of this study is the development of TPB model and the testing of the HEM model in an organic food purchase context. In this study, past experience and personal values have shown to be an important component that influenced attitude and purchasing behaviour. Therefore, past experience and personal values should be incorporated in the TPB model as influencing factors towards behavioural belief and attitude. Furthermore, the acceptance of all the hypotheses in this study and the findings have validated the three stages of HEM model of cognitive (motivational factors), affective (attitude) and conative (purchase) components.

From a managerial perspective, it is interesting and important to understand consumer attitude and purchase decision towards organic food. The findings of this study provide useful information to organic food retailers or marketers seeking to improve their sales, achieve continuous business growth and sustain in the market. The investigation on consumer motivational factors were meaningful for the retailers or marketers as they could plan and develop appropriate targeting and positioning strategies to increase consumers' demand on the organic food products in a growing market like Malaysia.

\section{Conclusion}

The findings have provided a valuable insights to the manufacturer, retailers or marketers on the importance of consumer motivational factors that affected their attitude to purchase organic food in Malaysia. Among the limitations of this study were the scope of the study, sampling size, measurement scale of variables and research design. The investigation from this study was only observed through the influence of the past experience, health consciousness and personal values and also confined to the area of Klang Valley in Malaysia. It is recommended that other external factors such as marketing, cultural or demographic in influencing consumer attitude and purchase of organic food should be explored for future studies. Data collection in different geographic areas in Malaysia would be useful for increasing sample representativeness and clarifying regional differences in consumers' purchase behaviour towards organic food.

Furthermore, future research can consider mixed research methods of quantitative and qualitative. The relationship between influencing factor, consumer attitude and actual purchase could be in depth investigated by using both quantitative and qualitative method to produce a good quality presentation of data analysis for the study.

\section{References}

Ajzen, I. (1985). From Intention to Actions: A Theory of Planned Behaviour. In Springer Series ini Sosial Psychology (pp. 11-39). Verlag Berlin Heidelberg: Springer Berlin Heidelberg.

Ajzen, I. (1991). The theory of planned behavior. Organizational Behavior and Human Decision Processes, 50(2), 179-211.

Ajzen, I., \& Albarracin, D. (2007). Predicting and changing behaviour: a reasoned action approach. Mahwah, NJ: Lawrence Erlbaum Associates.

Ajzen, I., \& Fishbein, M. (1980). Understanding attitudes and predicting social behavior. Englewood Cliffs, NJ: 
Prentice-Hall.

Bandura, A. (2001). Social cognitive theory: An agentive perspective. Annual Review of Psychology, 52, 1-26. https://doi.org/10.1146/annurev.psych.52.1.1

Barrett, P. (2007). Structural equation modelling: Adjudging model fit. Personality and Individual Differences, 42, 815-824. http://dx.doi.org/10.1016/j.paid.2006.09.018

Barry, T. F., \& Howard, D. J. (1990). A review and critique of the Hierarchy of Effects in advertising. International Journal of Advertising, 9(2), 121-135. http://dx.doi.org/10.1080/02650487.1990.11107138

Basha, M. B., Mason, C., \& Shamsudin, M. F. (2015). Consumers Attitude Towards Organic Food. International Accounting and Business Conference, 31, 444-452.

Bo, S. W. (2009). Factor Influencing Consumers' Perceptions, Intention to Purchase and Realised Purchase Behaviour for Organic Food in South Korea. (Doctorate Dissertation, University of Surrey). Retrieved April 20, 2017 from http://epubs.surrey.ac.uk/2873/

Browne, M. W., \& Cudeck, R. (1993). Alternative ways of assessing model fit. In: K.A.

Brunso, K., \& Scholderer, J. (2001). Consumer health consciousness and the organic food boom fact or fiction. Appetite, 37, 130.

Byrne, B. M. (2010). Structural equation modeling with AMOS (2nd ed.). New York: New York.

Chen, M. F. (2009). Attitude toward organic foods among Taiwanese as related to health consciousness, environmental attitudes, and the mediating effects of a healthy lifestyle. British Food Journal, 111(2), 165-178. http://dx.doi:10.1108/00070700910931986

Conner, M., Povey, R., Sparks, P., James, R. \& Shepherd, R. (2003). Moderating Role of attitudinal ambivalence within the theory of planned behaviour. British Journal of Social Psychology, 42, 75-94. http://dx.doi:10.1348/014466603763276135

Costa, S., Zepeda, L. \& Sirieix, L. (2011). Exploring the social value of organic food. In Consumer 2011, conference of the International Journal of Consumer Studies, Bonn, Germany, July,18-20.

Dangour, A.D., Lock, K., Hayter, A., Aikenhead, A., Allen, E. \& Uauy, R. (2010). Nutrition-related health effects of organic foods: A systematic review. The American Journal of Clinical Nutrition, 92(1), 203-210. http://dx.doi:10.3945/ajen.2010.29269

Denver, S. \& Jensen, J. D. (2014). Consumer Preferences for Organically and Locally Produced Apples. Food Quality and Preference, 31, 129-134. http://dx.doi:10.1016/j.foodqual.2013.08.014

Dettmann, R. L. \& Dimitri, C. (2010). Who's buying organic vegetables? Demographic characteristics of US $\begin{array}{lllll}\text { consumers. Journal of Food Products } & \text { Marketing, }\end{array}$ http://dx.doi.org/10.1080/10454440903415709

Dube, L., Cervellon, M. \& Han, J. (2003). Should consumer attitudes be reduced to their affective and cognitive bases? Validation of a hierarchical model. International Journal of Research in Marketing, 20, 259-272.

Fishbein, M. \& Ajzen, I. (1975). Belief, attitude, intention, and behavior: An introduction to theory and research. Reading, MA: Addison-Wesley.

Govindasamy, R., DeCongelio, M., Italia, J., Barbour, B. \& Anderson, K. (2001). Empirically Evaluating Consumer Characteristics and Satisfaction with Organic Products, Agricultural Experiment Station, Rutgers University, New Brunswick, NJ: New Jersey.

Guilford, J.P. (1956). Fundamental Statistics in Psychology and Education. New York: McGraw Hill.

Hair, J. F., Black, W. C., Babin, B. J. \& Anderson, R. E. (2010). Multivariate Data Analysis: A global perspective (7th ed.). New Jersey, NJ: Pearson Education Inc.

Harper, G. C., \& Makatouni, A. (2002). Consumer perception of organic food production and farm animal welfare. British Food Journal, 104(3/4/5), 287-299. https://doi.org/10.1108/00070700210425723

Honkanen, P. B. Verplanken, \& S. O. Olsen. (2006). Ethical values and motives driving organic food choice. Journal of Consumer Behaviour, 5(5), 420-430. http://dx.doi.org/10.1002/cb.190

Hsu, S.Y., Chang, C.C. \& Lin, T.T (2016). An analysis of purchase intentions toward organic food on health consciousness and food safety with/under structural equation modeling. British Food Journal, 118(1), 200-216. 
Khan, R. F. (2012). Effect of Brand Image on Self Image Congruency on Brand Preference and Customer Satisfaction. International Journal of Innovation in Business, 2(3), 92-102.

Lavidge, R. J. \& Steiner, G. A. (1961). A model for predictive measurements of advertising effectiveness. Journal of Marketing, 25(6), 59-62. http://dx.doi.org/10.2307/1248516

Lee, H. J. \& Goudeau, C. (2014). Consumers' beliefs, attitudes, and loyalty in purchasing organic foods: The standard learning hierarchy approach. British Food Journal, 116(6), 918-930. http://dx.doi:10.1108/BFJ-02-2013-0030

Lim, W. M., Li, S. Y. \& Suryadi, K. (2014).Consumers' Perceived Value and Willingness to Purchase Organic Food. Journal of Global Marketing, 27(5), 298-307. http://dx.doi.org/10.1080/08911762.2014.931501

Lockie, S., Lyons, K., Lawrence, G. \& Mummery, K. (2002). Eating "green": motivations behind organic food consumption in Australia. Sociologia Ruralis, 42(1), 23-40. http://dx.doi.org/10.1111/1467-9523.00200

Magnusson, M. K., Arvola, A., Hursti, U. K. K., Aberg, L. \& Sjoden, P. O. (2003). Choice of organic foods is related to perceived consequences for human health and to environmentally friendly behaviour. Appetite, 40(2), 109-117. http://dx.doi.org/10.1016/S0195-6663(03)00002-3

Magnusson, M. K., Arvola, A., KoivistoHursti, U-K., Aberg, L. \& Sjode'n, P-O. (2001). Attitudes towards organic foods among Swedish consumers. British Food Journal, 103(3), 209-26. http://dx.doi:10.1016/S0195-6663(03)00002-3

Makatouni, A. (2002). What motivates consumers to buy organic food in the UK? Results from a qualitative study. British Food Journal, 104(3-5), 345-352. http://dx.doi.:10.1108/00070700210425769

Michaelidou, N. \& Hassan, L. M. (2008). The role of health consciousness, food safety concern and ethical identity on attitudes and intentions towards organic food. International Journal of Consumer Studies, 32, 163-170. http://dx.doi.: 10.1111/j.1470-6431.2007.00619.x

Mohamad, S. S., Rusdi, S. D. \& Hashim, N. H. (2014). Organic Food Consumption among Urban Consumers: Preliminary Results. Procedia - Social and Behavioral Sciences, 130, 509-514. https://doi.org/10.1016/j.sbspro.2014.04.059

Padel, S. \&Foster, C. (2005). Exploring the gap between attitudes and behaviour. British Food Journal, 107(8), 606. http://dx.doi:10.1108/00070700510611002

Pallant, J. (2007). SPSS Survival Manual. Maidenhead: Open University Press.

Pearson, D., Henryks, J. \& Jones, H. (2010). Misreading between the lines: Consumer confusion over organic food labelling. Australian Journal of Communication, 37(3), 73-86.

Pellegrini, G. \& Farinello, F. (2009). Organic consumers and new lifestyles. An Italian country survey on consumption patterns. British Food Journal, 111(9), 948-974. https://doi.org/10.1108/00070700910992862

Roitner-Schobesberger, B., Darnhofer, I., Somsook, S. \& Vogl, C. R. (2008). Consumer perceptions of organic foods in Bangkok, Thailand. Food Policy, 33(2), 112-121. http://dx.doi.org/10.1016/j.foodpol.2007.09.004

Sangkumchaliang, P. \& Huang, W. (2012). Consumers' Perceptions and Attitudes of Organic Food Products in Northern Thailand. International Food and Agribusiness Management Review, 15(1), 87-102.

Schiffman, L. G. \& Kanuk, L. (2007). Consumer Behaviour (9th ed.). New Jersey: Prentice Hall.

Schiffman, L.G. (2008). Consumer Behaviour. US: Pearson Education Limited.

Schwartz, S. H. (1992). Universals in the Content and Structure of Values: Theoretical Advances and Empirical Tests in 20 Countries. Advances in Experimental Social Psychology, 25, 1-65.

Sia, B. K., Ooi, B. C., Chong, S.C, Lim, C. S., \& Low, L. T. (2013). Determinants of Willingness to Pay of Organic Products. Middle-East Journal of Scientific Research, 14(9), 1171-1179. http://dx.doi:10.5829/idosi.mejsr.2013.14.9.1959

Song, B. L., Safari, M., \& Mansori, S. (2016). The Marketing Stimuli Factors Influencing Consumers' Attitudes to Purchase Organic Food. International Journal of Business and Management, 11(10), 109-119. http://dx.doi:10.5539/ijbm.v11n10p109

Stratistics Market Research Consulting (2016). Organic Food and Beverage - Global Market Outlook (2016-2022). Retrieved July 11, 2017, from http://www.strategymrc.com/report/organic-food-and-beverage-market-2016 
Tarkianen, A. \& Sundqvist, S. (2005). Subjective norms, attitudes and intentions of Finnish consumers in buying organic food. British Food Journal, 107(11), 808-822. http://dx.doi:10.1108/00070700510629760

Tregear, A., Dent, J. B. \& McGregor, M. J. (1994). The demand for organically grown produce. British Food Journal, 96(4), 21-5. https://doi.org/10.1108/00070709410061032

Verbeke, W. \& Vackier, I. (2005). Individual determinants of fish consumption: application of the theory of planned behaviour. Appetite, 44, 67-82. http://dx.doi.org/10.1016/j.appet.2004.08.006

Voon, J. P., Kwang, S. N. \& Agrawal, A. (2011). Determinants of Willingness to Purchase Organic Food: An Exploratory Study Using Structural Equation Modeling. International Food and Agribusiness Management Review, 14(2), 103-120.

Wee, C.S., Ariff, M.S.B.M., Zakuan, N., Tajudin, M.N.M., Ismail, K. \& Ishak, N. (2014). Consumers perception, purchase intention and actual purchase behaviour of organic food products. Review of Integrative Business and Economics Research, 3(2), 378.

Zanoli, R., Bahr, M., Borschen, M., Laberenz, H., Naspetti, S. \& Thelen, E. (2004). The European consumer and organic food. Organic marketing initiatives and rural developmment (Vol. IV, p. 175). Aberystwyth: School of Management and Business, The University of Wales.

\section{Copyrights}

Copyright for this article is retained by the author(s), with first publication rights granted to the journal.

This is an open-access article distributed under the terms and conditions of the Creative Commons Attribution license (http://creativecommons.org/licenses/by/4.0/). 